\title{
Star fruit nephrotoxicity: a case series and literature review
}

Dilushi Rowena Wijayaratne ${ }^{1 *}$ (D, V. Bavanthan ${ }^{2}$, M. V. C. de Silva ${ }^{3}$, A. L. M. Nazar ${ }^{2}$ and Eranga S. Wijewickrama ${ }^{1,4}$

\begin{abstract}
Background: Star fruit is a popular medicinal fruit in the tropics. Its hypoglycaemic properties are considered useful in achieving glycaemic control in diabetes. Star fruit induced nephrotoxicity is a rare cause of acute kidney injury in individuals with both normal and reduced baseline renal function. We present three cases of acute kidney injury due to star fruit nephrotoxicity from Sri Lanka, and discuss the published literature on this topic.

Case presentation: Three Sri Lankan patients, all with a background of diabetes, presented to us with acute nausea and anorexia following recent consumption of star fruit. Two patients complained of diarrhoea and one patient complained of intractable hiccoughs. They all had elevated serum creatinine on admission. Two were known to have normal baseline serum creatinine levels. On renal biopsy two had evidence of oxalate crystal deposition. One did not show crystal deposition but had acute interstitial nephritis for which no alternate cause could be identified. Two were treated with short courses of prednisolone and two required acute haemodialysis. All recovered renal function, with both patients with known baselines approaching their premorbid serum creatinine levels.

Conclusion: Consumption of star fruit, especially on an empty stomach or in a state of dehydration may precipitate acute kidney injury. A history of star fruit ingestion must be actively looked for in patients presenting with unexplained acute kidney injury. The use of star fruit as a therapy for diabetes should be discouraged.
\end{abstract}

Keywords: Star fruit, Oxalate, Acute kidney injury

\section{Background}

Star fruit (Averrhoa carambola) is a popular fruit in Asian tropics. It is valued for its medicinal and nutritional properties [1]. Its hypoglycaemic effects are considered to be particularly beneficial in patients with diabetes mellitus, and it has been promoted as a traditional remedy for diabetes [2]. However, excessive consumption of star fruit has been associated with the development of oxalate nephropathy in patients with both normal and abnormal baseline renal function [3, 4]. Star fruit induced oxalate nephropathy remains an under-recognized cause for both acute and chronic kidney disease. We report three cases of acute kidney injury following ingestion of star fruit and discuss the literature related to star fruit toxicity and renal disease.

\footnotetext{
*Correspondence: dilushi_w@yahoo.com

'Univeristy Medical Unit, National Hospital of Sri Lanka, Colombo, Sri Lanka Full list of author information is available at the end of the article
}

\section{Case presentation \\ Case 1}

A 52-year-old male with a five-year history of type 2 diabetes mellitus presented with loose stools, abdominal pain and reduced urine output for two days. He had ingested of $200 \mathrm{ml}$ of homemade star fruit juice made from four whole star fruits a few hours prior to the onset of symptoms. Notably he complained of intractable hiccoughs. His serum creatinine three months prior to the presentation had been $0.7 \mathrm{mg} / \mathrm{dl}$. On admission he was mildly dehydrated and had a blood pressure of 140/ $90 \mathrm{mmHg}$. There was no evidence of diabetic retinopathy. Investigations revealed the following: haemoglobin$13.5 \mathrm{~g} / \mathrm{dl}$, white cell count - 17, 840/ cumm (Neutrophils $79 \%$, Lymphocytes- $10 \%$, Eosinophils- $0 \%$ ), platelets $345,000 /$ cumm, serum creatinine $4.5 \mathrm{mg} / \mathrm{dl}$, serum potassium $5.3 \mathrm{mmol} / \mathrm{l}$, serum sodium $138 \mathrm{mmol} / \mathrm{l}, \mathrm{C}-$ reactive protein- $164 \mathrm{mg} / \mathrm{l}$. The urine sediment was bland with no proteinuria. His Anti-nuclear antibody (ANA) titre, Anti-streptolysin O titre (ASOT), Hepatitis B, C serology, Antineutrophil cytoplasm antibody (ANCA)

(c) The Author(s). 2018 Open Access This article is distributed under the terms of the Creative Commons Attribution 4.0 International License (http://creativecommons.org/licenses/by/4.0/), which permits unrestricted use, distribution, and 
titre, and Complement 3 (C3) and Complement 4 (C4) levels were normal. Renal ultrasound showed normal kidneys with preserved cortico-medullary demarcation. Urine and blood cultures were sterile. He was commenced on intravenous cefotaxime for suspected sepsis. By day 5 of illness serum creatinine rose to $9 \mathrm{mg} / \mathrm{dl}$ leading to the initiation of haemodialysis.

Renal biopsy was done on the sixth day. This showed ten glomeruli, one of which was sclerosed, the others being normal. Some of the tubules showed oxalate crystals associated with acute tubular epithelial injury and evidence of regeneration. Patchy tubular atrophy was seen. The interstitium was oedematous and infiltrated by a moderate inflammatory infiltrate comprising lymphocytes, plasma cells, eosinophils and neutrophils. Mild interstitial fibrosis was seen. A diagnosis of star fruit induced oxalate nephropathy was made.

He required haemodialysis only once and was discharged on the seventh day with a falling serum creatinine. Serum creatinine three months later had stabilized at baseline levels.

\section{Case 2}

A 65-year-old male with a history of type 2 diabetes mellitus and hypertension presented with poor appetite, poor sleep, nausea and dyspeptic symptoms for five days. His urine output had been normal. On examination he was afebrile. His blood pressure was 120/70 mmHg. His laboratory investigations on admission revealed a serum creatinine of $7.3 \mathrm{mg} / \mathrm{dl}$ and serum $\mathrm{K}$ of $5.9 \mathrm{mmol} / \mathrm{l}$. His serum creatinine done seven months before had been $1.2 \mathrm{mg} / \mathrm{dl}$. Urinalysis was bland with no proteinuria. Serum ANA, ANCA, C3/C4, and Hepatitis B and C serology were normal.

He had not taken any prescription or over the counter medications in the recent past except for his usual anti diabetic medications. On direct questioning he admitted eating three fruits of star fruit immediately prior to the onset of symptoms. A clinical diagnosis of acute star fruit nephrotoxicity was made.

His serum creatinine remained static despite good urine output. A renal biopsy was performed due to the delay in recovery. It revealed acute tubulo-interstitial nephritis without oxalate deposition. Prednisolone was started at $30 \mathrm{mg}$ daily. His serum creatinine subsequently improved and 10 months later had reduced to $1.4 \mathrm{mg} / \mathrm{dl}$.

\section{Case 3}

A 57-year-old male with a history of hypertension and type 2 diabetes mellitus was admitted with loss of appetite, nausea and diarrhoea. On examination he was afebrile with a blood pressure of 140/90 $\mathrm{mmHg}$ and background diabetic retinopathy. His serum creatinine was $13.16 \mathrm{mg} / \mathrm{dl}$ on admission with serum potassium of $4.8 \mathrm{mmol} / \mathrm{l}$. His urinalysis revealed 8-10 pus cells and 35-40 red cells per high power field without any casts or proteinuria. His ANA, ASOT, Hepatitis B, C serology, ANCA and C3/C4 were normal. His renal ultrasonography showed normal sized kidneys with multiple calculi in the upper and middle calyces of the right kidney with cortical thinning and slightly increased cortical echogenicity of the left kidney.

On direct questioning he revealed having consumed on average one star fruit daily over the preceding one year with increased consumption to three fruits per day over the preceding one month.

He underwent several sessions of haemodialysis. A renal biopsy was performed which revealed tubular injury in the presence of oxalate crystals within the tubular lumina (Fig. 1). There was mild tubular atrophy and mild focal interstitial fibrosis. Some glomeruli were enlarged. Three glomeruli showed increase in mesangial

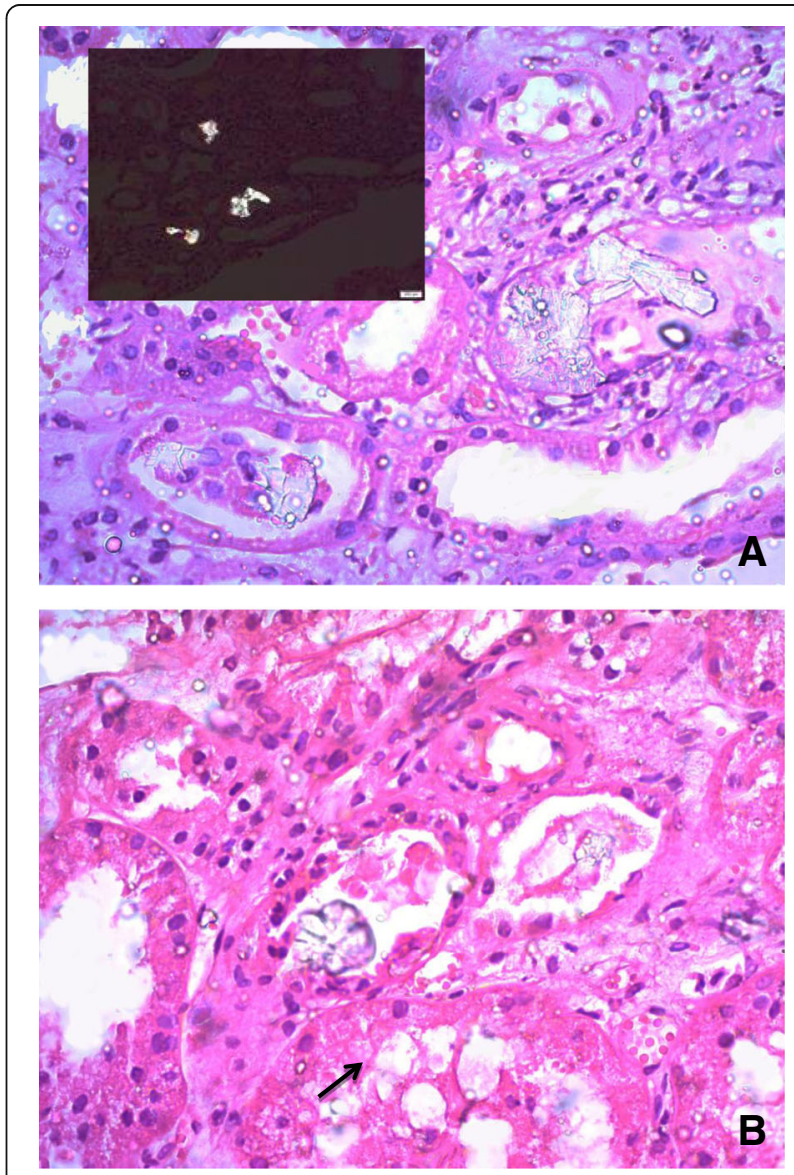

Fig. 1 a Renal biopsy specimen of Case 3 showing intratubular oxalate crystals. Insert shows oxalate crystals under polarized light. (Haematoxylin \& Eosin stain, X400). b Renal biopsy specimen of same patient showing focal attenuation of tubular epithelial cells with desquamation of cells. The tubule in the lower center shows cytoplasmic swelling and vacuolation, and intraluminal oxalate crystals (black arrow) 
matrix. Few glomerular capillaries showed thickened basement membranes Appearances were compatible with oxalate nephropathy occurring in the background of early diabetic nephropathy.

He was started on prednisolone $30 \mathrm{mg}$ daily. His serum creatinine subsequently improved and had reduced to $2.98 \mathrm{mg} / \mathrm{dl}$ two months after the initial admission.

\section{Discussion}

Averrhoa carambola (star fruit), a member of the Oxalidaceae family, is rich in oxalic acid. The content of oxalate varies according to the type of star fruit, being higher in the sour type than in the sweet [5]. Total consumption is often higher when consumed as a juice than as a single whole fruit. The oxalic acid content of fresh juice was measured by Chen et al. as $202 \mathrm{mg} / \mathrm{dl}$ in fresh sweet juice and $829 \mathrm{mg} / \mathrm{dl}$ in fresh sour juice [6].Commercial preparations of star fruit juice are processed by pickling and diluting procedures which lower oxalate concentrations. In comparison homemade and medicinal preparations of pure sour star fruit juice often have high concentrations of oxalate [6].

In the gastro intestinal tract ingested oxalates complex with intraluminal calcium and magnesium to form insoluble complexes, which prevent them from getting absorbed [6]. When consumed in large amounts, especially in the fasting state, more free oxalates remain available for absorption into the circulation. Circulating free oxalates are filtered through the kidneys where they precipitate into calcium oxalate crystals and mediate renal damage by means of tubular obstruction. The formation of highly concentrated urine in the dehydrated state predisposes to crystal deposition. Typical histological findings include intraluminal and intraepithelial deposition of colourless oxalate crystals. When examined under polarized light these crystals exhibit a pattern of birefringence including all colours of the rainbow. Crystals appear blue in haematoxylin-eosin stain and black in von Kossa's stain. With transmission electron microscopy, oxalate crystals appear mainly as long needles with blunt edges [7]. Some studies have shown a high serum oxalate level to be associated with increased apoptosis of renal epithelial cells which contributes to nephrotoxicity [8].

As yet there is no described toxic dose of star fruit juice. Toxicity is affected by the type of star fruit preparation as well as patient hydration and the fasting/ feeding state. Many patients with star fruit toxicity present within hours of ingestion with gastrointestinal symptoms such as vomiting and abdominal pain. These are suspected to be due to direct corrosive effects of dietary oxalates rather than systemic effects [9]. This may be followed by a reduction in urine output in patients who develop acute kidney injury. It has been suggested that the accumulation of the toxin caramboxin in patients with renal impairment results in the neuropsychiatric manifestations of star fruit toxicity. These include hiccoughs, confusion, insomnia and seizures [10]. One of our patients had intractable hiccoughs on presentation, a possible clue to the underlying diagnosis.

There are many cases of star fruit toxicity reported in the literature (Table 1) $[3,4,6,8,10-35]$. The toxic effects of star fruit were first described among patients with preceding renal impairment and were characterized by prominent neurotoxic features $[4,10,11]$. More recently, a total of 27 cases of acute kidney injury in patients with normal renal functions have been reported $[6,8,29,31-34]$. The apparent increase in the reports of acute nephrotoxicity may reflect increasing awareness of the condition. Specific details about the clinical presentation and management of those with normal baseline creatinine were available for twelve of these cases. Neurotoxic features were seen in six out of twelve of these patients. While patients with underlying chronic kidney disease presented with toxic features after consumption of as little as half a star fruit, in those with normal renal function the minimal reported toxic doses were 4-6 star fruits or $300 \mathrm{ml}$ of star fruit juice. All nine renal biopsies which had been done in previous studies, (two with background chronic kidney disease) showed evidence of oxalate deposition in renal tissue. Out of those twelve patients with normal baseline creatinine three required renal replacement therapy for treatment of acute kidney injury. Recovery was the norm. Only three of the 27 cases with normal renal function progressed to chronic kidney disease, with one becoming dialysis dependent.

A case of chronic kidney disease attributable to frequent ingestion of star fruit was recently reported from Sri Lanka [32]. It has been suggested that chronic kidney disease may result from calcium oxalate induced interstitial inflammation, fibrosis and nephron loss. Two of our patients had normal premorbid serum creatinine which returned to baseline with time, indicative of pure acute kidney injury. The third had evidence of concomitant diabetic nephropathy on renal biopsy. In our series two patients had oxalate crystals while one had only features of acute interstitial nephritis. This highlights the need for obtaining a history of ingestion of potential nephrotoxins in a patient with unexplained acute kidney injury. It is interesting to note that both previous cases reported from Sri Lanka were also diabetic patients [32]. This may reflect the common use of star fruit among diabetics in Sri Lanka as a remedy to reduce the blood glucose levels or alternatively suggest an increased susceptibility in this group. The prevalence of diabetes as a comorbidity is $42.1 \%$ among reported cases in the literature. However, data is inadequate to comment on 


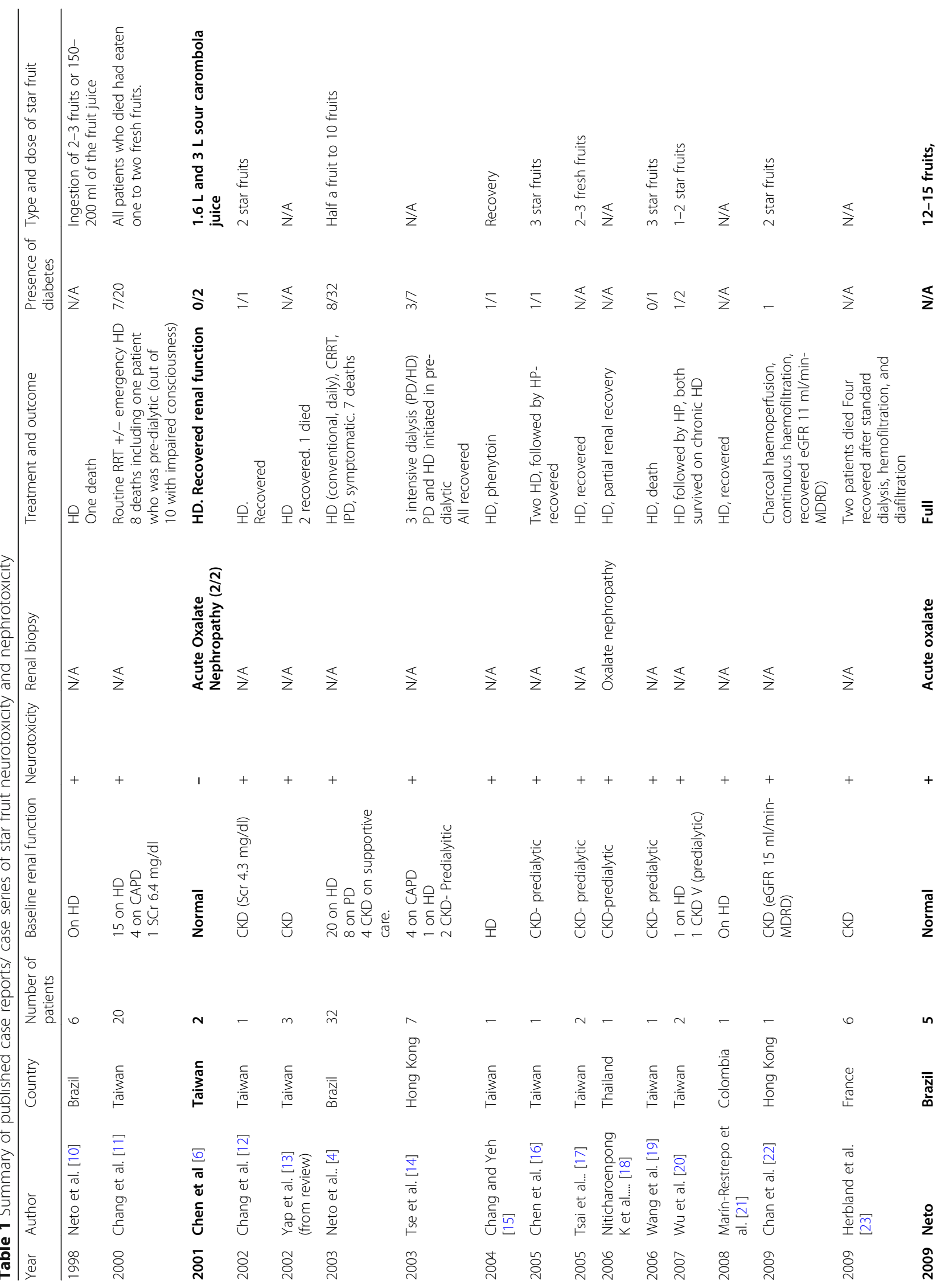




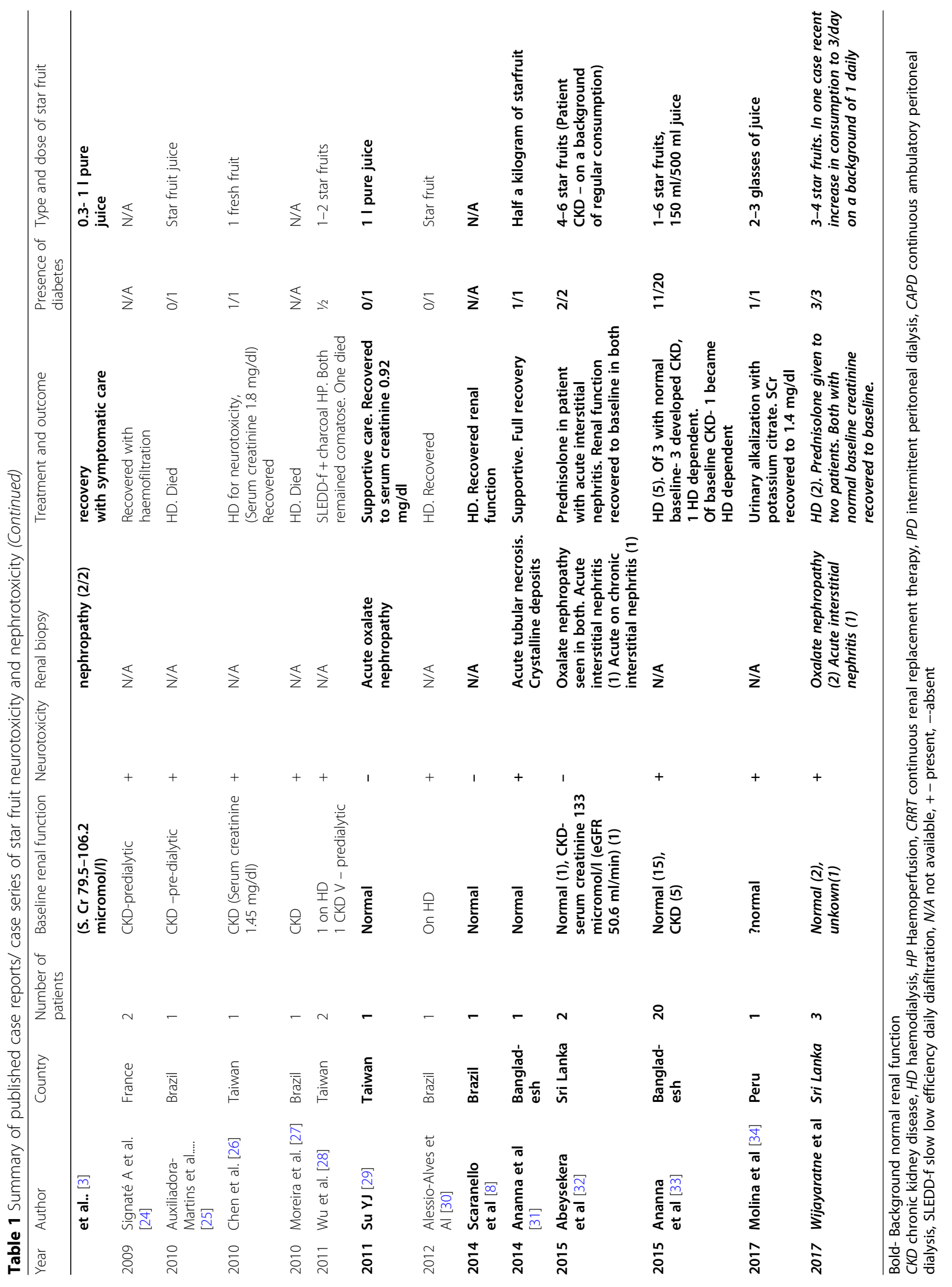


the prevalence of diabetes in those with normal baseline renal function. The fat malabsorption seen in chronic pancreatitis (a cause of diabetes) and diabetic gastroentoropathy (a complication of diabetes) may be associated with acute oxalate nephropathy [36, 37]. The free fatty acids that remain unabsorbed in the colonic lumen bind to calcium ions and prevent the precipitation of oxalate. Free oxalate can be absorbed in to the bloodstream and filtered in the kidney, as described above. The three patients in our series did not have clinical features of malabsorption. However, it would be interesting to study if subclinical degrees of malabsorption in diabetic patients predispose to oxalate nephropathy in the presence of an acute oxalate load.

There is no specific treatment for star fruit induced acute kidney injury. In those who require renal replacement therapy haemodialysis and haemoperfusion are preferred. Based on experience in the use of haemodialysis in the setting of primary hyperoxaluria, these methods may benefit patients by increasing the clearance of oxalate, apart from the removal of uremic toxins [38]. None of the studies described the use of haemodialysis for the sake of removal of oxalate per se without any other nephrological indications. However, it has been suggested that haemodialysis should be performed early if the disturbance in the conscious level of the patient is suspected to be directly related to star fruit intoxication rather than due to the resultant renal impairment [12].Peritoneal dialysis has been shown to be of no benefit, especially in patients with neurological features [4]. Though many nephrologists use steroids for the management of acute oxalate nephropathy, there are no studies to support this, and spontaneous recovery is the rule. Recently the effect of $\mathrm{N}$ - acetyl cysteine (NAC) on star fruit induced acute kidney injury was studied in animal models. The results suggest that NAC may attenuate renal dysfunction by means of reducing oxidative stress, oxaluria and inflammation [39].

\section{Conclusion}

Star fruit nephrotoxicity must be considered in any individual developing unexplained acute kidney injury. The history is the key to reach a diagnosis early. As yet, there are no proven specific therapies and management is supportive. It is essential to prevent star fruit nephrotoxicity by educating the public and especially diabetics to avoid consuming star fruit, especially on an empty stomach or in a dehydrated state. Further studies need to be done to identify the dose and type of star fruit, which could lead to nephrotoxicity. In the interim the use of star fruit, specifically as a therapy to achieve better glycaemic control in diabetes, should be discouraged.

\section{Abbreviations}

ANA: Antinuclear antibody; ANCA: Anti-neutrophil cytoplasm antibody; ASOT: Anti-streptolysin O titre; C3: Complement 3; C4: Complement 4; cumm: Cubic millimitre; dl: Decilitre; g: Gram; I: Litre; mg: Milligram; $\mathrm{ml}$ : Millilitre; mmHg: Millimetres of mercury; mmol: Millimole; NAC: Nacetylcysteine

\section{Acknowledgements}

The medical staff of the University medical Unit and Nephrology, Dialysis and Transplant Unit, National Hospital, Sri Lanka.

\section{Availability of data and materials}

All data generated or analysed during this study are included in this published article.

\section{Authors' contributions}

All the authors were involved in the management of these patients. CD performed the histological examination of renal biopsies. DW, VB, CD and EW participated in acquisition of data. DW and EW were involved in drafting the manuscript. DW, EW, VB, CD and AN participated in revising the manuscript critically and giving the final approval of the version to be published.

\section{Ethics approval and consent to participate}

Ethical approval was not deemed necessary as the data was collected in retrospect and patients had received the usual standard of care. Thus, all diagnostic and therapeutic interventions the patients had received were in keeping with the standard practices of our respective units. No intervention had been performed for the purpose of report. The anonymity of the patients has been maintained in our report.

\section{Consent for publication}

Written informed consent was obtained from the patients for publication of this case series and any accompanying images. A copy of the written consent is available for review by the Editor-in-Chief of this journal.

\section{Competing interests}

The authors declare that they have no competing interests.

\section{Publisher's Note}

Springer Nature remains neutral with regard to jurisdictional claims in published maps and institutional affiliations.

\section{Author details}

${ }^{1}$ Univeristy Medical Unit, National Hospital of Sri Lanka, Colombo, Sri Lanka. ${ }^{2}$ Nephrology, Dialysis and Transplant Unit, National Hospital of Sri Lanka, Colombo, Sri Lanka. ${ }^{3}$ Department of Pathology, Faculty of Medicine, University of Colombo, Colombo, Sri Lanka. ${ }^{4}$ Department of Clinical Medicine, Faculty of Medicine, University of Colombo, Colombo, Sri Lanka.

Received: 5 November 2017 Accepted: 8 October 2018

Published online: 22 October 2018

\section{References}

1. Muthu N, Lee SY, Phua KK, Bhore SJ. Nutritional, medicinal and toxicological attributes of star-fruits (Averrhoa Carambola L.): a review. Bioinformation. 2016;12:420-4. https://doi.org/10.6026/97320630012420.

2. Gunasekara LCA, Fernando PHP, Sivakanesan R. A Preliminary Study on the Hypoglycaemic Effect of Averrhoa carambola (Star Fruit) in Rats, vol. 16. Sri Lanka: Proceedings of the Peradeniya University Research Sessions; 2011. p. 83.

3. Neto MM, Silva GEB, Costa RS, et al. Star Fruit: Simultaneous Neurotoxic and Nephrotoxic Effects in People with Previously Normal Renal Function. NDT Plus. 2009;2(6):485-8. https://doi.org/10.1093/ndtplus/sfp108.

4. Neto MM, da Costa JA, Garcia-Cairasco N, Netto JC, Nakagawa B, Dantas M. Intoxication by star fruit (AverrhoaCarambola) in 32 Uraemic patients: treatment and outcome. Nephrol Dial Transplant. 2003;18:120-5.

5. Morton JF. Fruits of warm climates. Miami: Florida Flair Books; 1987.

6. Chen $\mathrm{CL}$, Fang HC, Chou KJ, Wang JS, Chung HM. Acute oxalate nephropathy after ingestion of star fruit. Am J Kidney Dis. 2001;37:418-22. 
7. Seshan SV, Dagati VD, Appel GA, Churg J. Renal Disease Classification and Atlas of Tubulointerstitial and Vascular Diseases. Baltimore: Williams \& Wilkins; 1999. p. 234-5.

8. Fang H-C, Lee P-T, Lu P-J, Chen C-L, Chang T-Y, Hsu C-Y, Chung H-M, Chou K-J. Mechanisms of star fruit-induced acute renal failure. Food Chem Toxicol. 2008:46:1744-52

9. Konta T, Yamaoka M, Tanida H, Matsunaga T, Tomoike H. Acute renal failure due to oxalate ingestion. Intern Med. 1998;37:762-5.

10. Neto MM, Robl F, Netto JC. Intoxication by star fruit (Averrhoacarambola) in six dialysis patients? (preliminary report). Nephrol Dial Transplant. 1998;13:570-2.

11. Chang JM, Hwang SJ, Kuo HT, Tsai JC, Guh JY, Chen HC, Tsai JH, Lai YH. Fatal Outcome after Ingestion of Star Fruit (AverrhoaCarambola) in Uremic Patients. Am J Kidney Dis. 2000;35:189-93.

12. Chang CT, Chen YC, Fang JT, Huang CC. Star fruit (Averrhoacarambola) intoxication: an important cause of consciousness disturbance in patients with renal failure. Ren Fail. 2002;24:379-82.

13. Yap HJ, Chen YC, Fang JT, Huang CC. Star fruit: a neglected but serious fruit intoxicant in chronic renal failure. Dial Transplant. 2002;31:564-97.

14. Tse KC, Yip PS, Lam MF, et al. Star fruit intoxication in uraemic patients: case series and review of the literature. Intern Med J. 2003;33:314-6.

15. Chang $\mathrm{CH}$, Yeh JH. Non-convulsive status epilepticus and consciousness disturbance after star fruit (Averrhoacarambola) ingestion in a dialysis patient. Nephrology (Carlton). 2004;9:362-5.

16. Chen LL, Fang JT, Lin JL. Chronic renal disease patients with severe star fruit poisoning: Hemoperfusion may be an effective alternative therapy. ClinToxicol (Phila). 2005;43:197-9.

17. Tsai MH, Chang WN, Lui CC, et al. Status epilepticus induced by star fruit intoxication in patients with chronic renal disease. Seizure. 2005;14:521-5.

18. Niticharoenpong K, Chalermsanyakorn P, Panvichian R, Kitiyakara C. Acute deterioration of renal function induced by star fruit ingestion in a patient with chronic kidney disease. J Nephrol. 2006;19:682-6.

19. Wang YC, Liu BM, Supernaw RB, Lu YH, Lee PY. Management of star fruitinduced neurotoxicity and seizures in a patient with chronic renal failure. Pharmacotherapy. 2006;26:143-6.

20. Wu MY, Wu IW, Wu SS, Lin JL. Hemoperfusion as an effective alternative therapy for star fruit intoxication: a report of 2 cases. Am J Kidney Dis. 2007:49:e1-5.

21. Marín-Restrepo L, Rosselli D. Intoxication with Averrhoa carambola in a patient on chronic dialysis. Nefrologia. 2008;28:117-8.

22. Chan CK, Li R, Shum HP, et al. Star fruit intoxication successfully treated by charcoal haemoperfusion and intensive haemofiltration. Hong Kong Med J. 2009;15:149-52

23. Herbland A, El Zein I, Valentino R, et al. Star fruit poisoning is potentially lifethreatening in patients with moderate chronic renal failure. Intensive Care Med. 2009;35:1459-63.

24. Signaté A, Olindo S, Chausson N, et al. Star fruit (Averrhoacarambola) toxic encephalopathy. Rev Neurol (Paris). 2009;165:268-72.

25. Auxiliadora-Martins M, Alkmin Teixeira GC, da Silva GS, et al. Severe encephalopathy after ingestion of star fruit juice in a patient with chronic renal failure admitted to the intensive care unit. Heart Lung. 2010;39:448-52.

26. Chen SH, Tsai MH, Tseng YL, Tseng YL, Lui CC, Chuang YC. Star fruit intoxication in a patient with moderate renal insufficiency presents as a posterior reversible encephalopathy syndrome. ActaNeurol Taiwan. 2010;19:287-91.

27. Moreira FG, lervolino RL, Dall'Orto SZ, Beneventi AC, Oliveira Filho $J$, Góis AF. Star fruit intoxication in a chronic renal failure patient: case report. Rev Bras Terlntensiva. 2010;22:395-8.

28. Wu CL, Chiu PF, Yang Y, Wen YK, Chiu CC, Chang CC. Sustained lowefficiency daily diafiltration with hemoperfusion as a therapy for severe star fruit intoxication: a report of two cases. Ren Fail. 2011;33:837-41.

29. Su YJ, Lee CH, Huang SC, Chuang FR. Quiz page April 2011. A woman with oliguria. Acute oxalate nephropathy caused by excess intake of pure carambola juice. Am J Kidney Dis. 2011;57:A23-5.

30. Alessio-Alves FF, de Souza CP, da Silva LK, Moyses-Neto M, Pontes-Neto OM. Starfruit neurotoxicity mimicking an acute brainstem stroke. Clin Neurol Neurosurg. 2012;114:684-5.

31. Ananna MA, Hasan R, Samad T, Rahim MA, Rafman ME, Haque WM, Billah M, Hoque HF, Afroz F, Afroz SR, lqbal PMS. Acute kidney injury due to star fruit ingestion: a case report. BSMMU J. 2014;7:151-3.

32. Abeysekera RA, Wijetunge S, Nanayakkara N, et al. Star fruit toxicity: a cause of both acute kidney injury and chronic kidney disease: a report of two cases. BMC Res Notes. 2015;8:796.
33. Ananna MA, Iqbal S, Samad T, Rahim MA, Haque WMM, Chowdhury TA, Arafat SM, Mitra P. SP229 Nephrotoxicity caused by star fruit ingestion in 20 patients and their outcome: an experience from Bangladesh. Nephrol Dial Transplant. 2015:30 Suppl 3:iii453 https://doi.org/10.1093/ndt/gfv190.41.

34. Molina M, Morales E, Navarro B, Moliz C, Praga M. La frutaestrellacausafracaso renal agudo. Nefrologia. 2017;37:221-2.

35. Aranguren C, Vergara C, Rosselli D. Toxicity of star fruit (Averrhoacarambola) in renal patients: a systematic review of the literature. Saudi J Kidney Dis Transpl. 2017;28:709-15.

36. Crook ED, et al. Rapid renal deterioration secondary to oxalate in a patient with diabetic gastroenteropathy. Am J Kidney Dis. 1995;26:68-71.

37. Cartery C, Faguer S, Karras A, et al. Oxalate nephropathy associated with chronic pancreatitis. Clin J Am Soc Nephrol. 2011;6:1895-902. https://doi. org/10.2215/CJN.00010111.

38. Lorenz EC, Michet CJ, Milliner DS, Lieske JC. Update on oxalate crystal disease. Curr Rheumatol Rep. 2013;15:340. https://doi.org/10.1007/s11926013-0340-4.

39. Shimizu MH, Gois PH, Volpini RA, Canale D, Luchi WM, Froeder L, Heilberg IP, Seguro AC. N-Acetylcysteine Protects against Star Fruit-Induced Acute Kidney Injury. Renal Failure. 2017;39:193-202. https://doi.org/10.1080/ $0886022 \times .2016 .1256315$
Ready to submit your research? Choose BMC and benefit from:

- fast, convenient online submission

- thorough peer review by experienced researchers in your field

- rapid publication on acceptance

- support for research data, including large and complex data types

- gold Open Access which fosters wider collaboration and increased citations

- maximum visibility for your research: over $100 \mathrm{M}$ website views per year

At BMC, research is always in progress.

Learn more biomedcentral.com/submissions 